доктор психологічних наук, професор, завідувач кафедри вікової та педагогічної психології Рівненського державного гуманітарного університету http://orcid.org/0000-0002-6564-4507.

Корчакова Наталія доктор психологічних наук, професор кафедри вікової та педагогічної психології Рівненського державного гуманітарного університету http://orcid.org/0000-0003-1164-3370

Безлюдна Валентина кандидат педагогічних наук, доцент, професор кафедри вікової та педагогічної психології http://orcid.org/0000-0003-3276-3427 DOI https://doi.org/10.35619/praprv.v1i15.194

\title{
ПРОБЛЕМА ПРОСОЦІАЛЬНОГО РОЗВИТКУ ОСОБИСТОСТІ У СТРУКТУРІ ОСВІТНЬОГО КОНТЕНТУ
}

Анотація. Однією з центральних ліній трансформування вищої освіти в Украйні є оновлення інформаційних потоків, щзо транслюються майбутнім фахівиям у процесі вузівського навчання. Відбір новітніх ідей та їх привнесення у структуру навчальних дисциплін є одним із завдань викладача вищої школи. Просоціальна проблематика, як нова лінія психологічних знань, повинна зайняти належне місие у професійній підготовці фахівиів суб'єкт-суб'єктного спрямування. Ця необхідність детермінується значущістю проблеми просоціальності особистості та ї̈ інтенсивним вивченням у останній період. Просоціальна поведінка - особливий вид сочіальної активності людини, мета якої - підтримка Іншого, надання йому сприяння $i$ допомоги у задоволенні потреб іншої людини та реалізації ї̈ намірів. Диспозиційною основою такої поведінки особистості $\epsilon$ просочіальність особистісна якість, щуо має складну будову та тривалий илях онтогенетичного становлення.

Питання просоціального розвитку особистості доцільно включити у програми викладання таких навчальних дисциилін як вікова та соиіальна психологія. Привнесення тих чи інших матеріалів з питань розвитку просоціальності особистості повинно узгоджуватися із основними ціляями курсів. У лоні навчальної дисципліни «соціальна психологія» майбутніх психологів $i$ вчителів доречно ознайомити із сутністю понять «просочіальна поведінка» $i$ «просочіальність», $\ddot{x}$ диспозичійною $i$ ситуативною детермінацією, основними різновидами короткотривалих $i$ довготривалих форм просочіальної поведінки. Програма освітнього контенту з вікової психологї повинна доповнитися матеріалами вікового тенезу просочіальних тенденцій особистості від зародження елементарних форм сприяння у період раннього дитинства до зрілих гуманістично зорієнтованих стратегій поведінки у дорослому та похилому віці.

Ключові слова: освітній контент, програми навчальних курсів, просочіальна поведінка, просоиіальність, вікова генеза, студенти.

Постановка проблеми. Одним із стратегічних завдань реформування вищої освіти в Україні $є$ інтенсифікація принципу науковості та практичної значущості інформації, що надається студенту у процесі професійної підготовки. XX і XXI століття - етапи швидкого розширенням наукового пізнання, нагромадження все-нових i нових знань у кожній iз галузей науки, виникнення дотичних інформаційних потоків, що видозмінюють традиційні погляди. Ці процеси не оминули і психологічну науку. Незважаючи на те, що гуманітарні 
науки є більш консервативними, у порівнянні з технічними чи економічними, і процес «старіння» наукових знань відбувається в них більш повільно, наявність значного розриву між рівнем наукового пізнання і інформаційним контентом навчальних дисциплін не допустимий. Якщо 30-35 років тому назад в науці обговорювалися ідеї подвоєння наукової інформації раз у 7-8 років, то на сьогодні цей показник для більшості наукових ліній знизився до 3-4 років, а показник старіння знань випускника ВНЗ за час професійного навчання навпаки підвищився із 4-5 відсотків до 8-12.

Основним шляхом запобігання виникненню розбалансувань між рівнем наукового пізнання і знаннями студента $€$ постійне оновлення змістового компоненту викладання дисциплін психологічного циклу. Це стосується як доповнення новітньою інформацією традиційних змістовних модулів, так і виокремлення нових ліній у розкритті психологічної сутності людини та іï розвитку. Оскільки сучасне планування навчальних дисциплін та визначення їх інформаційного контенту покладено на викладача вузу, він повинен мати високий рівень готовності до аналізу потоків наукової інформації та здійснення її методичної обробки.

Метою повідомлення є обговорення ідеї привнесення питань просоціального розвитку особистості у навчальні курси з вікової та соціальної психології при здійснені професійної підготовки майбутніх психологів, вихователів та вчителів у вищій школі.

Доцільність і своєчасність ознайомлення майбутніх фахівців у галузі педагогічної i психологічної професійної діяльності з основами просоціальної проблематики зумовлена, за нашим розумінням, суспільно-побутовими та загальнонауковими підставами. Зокрема, до першої групи можна віднести сукупність несприятливих тенденцій у розвитку суспільства, що спричиняють виокремлення просоціальної проблематики у розряд пріоритетних, суспільно-значимим завданням. До цих змінних можна віднести:

- зростання агресивних тенденцій та проявів жорстокості у соціальній взаємодії людей, що зумовлені загальною нестабільністю та кризовістю сучасного соціальноекономічному розвитку суспільства;

послаблення особистісного контексту у взаємодії і спілкуванні між людьми, що приводить до їх збайдужіння, втрати емпатійної чутливості до проблем і інтересів інших;

- загострення булінгових процесів у дитячих та підліткових спільнотах;

- розгортання кіберзнущань у віртуальному просторі.

До другої групи змінних можна віднести наукові надбання, які розкривають сутність просоціальності та просоціальної поведінки особистості. На сьогодні, психологічна i педагогічна наука володіє достатньо широкою інформацію про ці взаємопов'язані соціальнопсихологічні феномени. Саме обговоренню цих надбань і присвячене наше повідомлення.

Отже, спробуємо позначити основні блоки інформації 3 питань просоціальної проблематики, які доречно включити до навчальних програм вищеозначених навчальних дисциплін. На нашу думку, студентів доречно ознайомити із сутністю просоціальної поведінки особистості, iii основними різновидами, структурою просоціальності як особистісної якості, джерелами іiі формування, віковими етапами становлення феномену, лінією генезису просоціальності на кожному із вікових етапів, шляхами стимулювання іiі розвитку.

Історичний екскурс аналізу проблеми засвідчує, що вивчення просоціальних тенденцій особистості започатковано у зарубіжній психологічній науці у 70-80 роках XX. Спочатку увага психологів зосереджувалася на вивченні поведінкового феномену - наданні допомоги Іншому (Paulus, 2011;) і лише поступово була виокремлена його внутрішня складова - просоціальність як особистісна якість (Bierhoff, 2004; Bischof-Köhler, 2016; Penner, 2006; Rushton, 2008). У вітчизняній науці проблема просоціальної поведінки та про соціальності на початкових етапах більш інтенсивно розроблялася у педагогічній науці (Врочинська, 2008; Грищенко, 2009; Кириченко, 2014) і лише в останньому десятиріччі з'явилися роботи психологічного спрямування (Багмет, 2004; Журавльова, 2009; Корчакова, 2018; Наконечна, 2012; Петренко, 2012). 
Враховуючи об’єкт та предмет двох навчальних дисциплін (вікової та соціальної психології) варто розмежувати сферу аналізу просоціального феномену. Зокрема, у соціальній психології студентів необхідно познайомити із різними підходами до визначення сутності понять «просоціальна поведінка» та «просоціальність», забезпечивши при цьому розмежування трьох видів гуманістично зорієнтованої поведінки: просоціальної, моральної та альтруїстичної поведінки. У теоретичних джерелах існує багато точок зору щодо цих питань. Ми схиляємося до найбільш узагальненого визначення поняття просоціальної стратегії, яке охоплює розмаїття поведінкових проявів, які можуть докорінно різнитися за характером мотиваційних спонук, але об'єднані ідеєю соціальної корисності дії суб'єкта. Просоціальна поведінка - це дія на благо Іншого. Відповідно це широке, інтегроване поняття об'єднує у єдину структуру як альтруїстичні дії особистості, засновані на системі моральних приписів, так і вчинки, у основі яких лежать інші мотиваційні спонуки. До основних із них належать егоїстичні мотиви, презентаційні, мотиви принциповості. Їх виокремлення і опис $\epsilon$ також предметом соціальної психології. При цьому важливе значення для розуміння сутності просоціальної поведінки має ознайомлення студентів із дією ситуативних і диспозиційних чинників, що обумовлюють той чи інший тип поведінки особистості у ситуаціях просоціального типу.

Для структурування уявлень студентів щодо розмаїття просоціальних самовиявів особистості у програмі курсу доречно передбачити їх ознайомлення із основними підходами щодо класифікації видів просоціальних дій. Зокрема, за критерієм тривалості виокремлюють короткотривалі і довготривалі форми сприяння (донорство, волонтерство). За характером ситуації, у якій особистість продукує сприяючі дії вони поділяются на дії анонімного характеру, прояву допомоги у публічних ситуаціях, дії сприяння у відповідь на прохання про допомогу чи при відсутності такого запиту (Carlo, 2002).

При обговоренні сутності просоціальності як особистісної якості варто ознайомити студентів із двома лініями аналізу цього утворення у психологічній науці. Перший напрямок пов'язаний із вивченням схильності людини до гуманістичних самовиявів. Він передбачає диференціацію типів особистості за критерієм просоціальних налаштувань (Братусь, 1988). Другий напрямок аналізу - це виокремлення структурних компонентів особистісної якості «просоціальність», побудова іiі моделі (Ігноцька, 2012; Dunfield, 2014; Penner, 2002; Корчакова, 2018). Результатом таких досліджень є розробка портрету просоціальної особистості, виокремлення іiі найбільш значущих якостей, таких як емпатійність, віра у справедливість, соціальна відповідальність, внутрішній локус контролю, низький рівень егоцентризму, сформовані моральні судження.

При розробці програми курсу соціальної психології доречним $є$ і ознайомлення студентів із надбаннями психологічної науки у галузі розробки діагностичного інструментарію по вивченню просоціальності особистості та просоціальної поведінки. Увагу студентів доречно спрямувати на ознайомлення із такими методиками як «Мотивація допомоги» (авт. С. К. Нартова-Бочавер), «Діагностика особистісної соціально-психологічної установки «альтруїзм - егоїзм» (авт. О. Ф. Потьомкіна), «Шкала емоційного відгуку» (авт. А. Меграбян, модиф. Н. Епштейна), «Справедливість - турбота» (авт. С. В Молчанов), «Субшкала альтруїзму» (авт. П. Робінсон, Р. Шейвер, адапт. Н. В. Кухтової), «Зміст просоціальної ідентичності» (авт. А. Дж. Барріга, адапт. Н.В Кухтової), «Шкала диспозиційного егоїзму» (авт. К. Муздибаєв), «Емоційна, когнітивна і дієва емпатія» (авт. О. А. Троїцька), «Вимірювання просоціальних тенденцій» (авт. Г. Карло, Б. Рендалл, адап. Н. В. Кухтової), «Просоціальна особистість» (Л. Пеннер, адапт. М. В Петренко), «Соціальні норми просоціальної поведінки» (авт. І. А. Фурманов, Н. В. Кухтова), «Методика вимірювання турботи», (авт. Х. Когут, Б. Дж. Бум; адапт. І. А. Фурманова, Н. В. Кухтової). Знання діагностичного інструментарію забезпечить наближення теоретичних знань студентів до вирішення конкретних завдань професійної діяльності психолога 3 питань аналізу просоціальної поведінки особистості та їі стимулювання.

Перейдемо до аналізу змістового контенту просоціальної проблематики, який доречно включити у програми курсу «вікова психологія». Як і у попередньому випадку, наголосимо, 
що нова інформація повинна бути співзвучною меті та завданням навчальної дисципліни, релевантною іiі основним ідеям. Варто відзначити, що питання вікового генезу просоціального феномену почали інтенсивно вивчатися лише у останні 15-20 років, але уже на сьогодні психологічна наука має надбання, які здатні розширити і уточнити знання про онтогенетичні закономірності особистісного розвитку. Зокрема, дослідження вікової траєкторії розвитку просоціальної поведінки відкривають новий ракурс аналізу процесу соціалізації на різних етапах онтогенезу. Частина із них охоплюють широкі вікові діапазони (Eisenberg 2006; House, 2012; Nantel-Vivier, 2009), інші - зосереджуються на глибинному аналізі динаміки просоціального розвитку у межах певного періоду. На сьогодні кожний із вікових періодів достатньо широко представлений у системі емпіричного аналізу, що створює можливість збагачувати новою інформацією усі теми змістових модулів вікової психології.

У курсі вікової психології необхідно передбачити ознайомлення студентів із витоками просоціальності особистості, первинними формами просоціальних самовиявів у період раннього дитинства. Для розкриття цих явищ корисним буде ознайомлення із дослідженнями Warneken, 2013; Tomasello, 2013, що висвітлюють особливості сприйняття приматами та дітьми 2-3 року життя ситуацій із просоціальним контекстом та їх спробами приходити на допомогу дорослим. Доречним для систематизації знань з питань просоціального розвитку $є$ виокремлення основних різновидів просоціальних самовиявів, що запропоновані у роботах Dunfield, 2014. Згідно підходу цього автора усе розмаїття просоціальних дій поділяють на дії допомоги, емоційного сприяння, обміну та дарування. Кожна із цих форм поведінки має свої особливості вікового генезу. Онтогенетично первинною ввжається інструментальна допомога (Нерасh, 2013;2017; Свєтлова, 2010; Brownel, 2006; Paulus, 2015). У найпростіших формах вона простежується починаючи з другого року життя дитини. У іiї основі лежать два детермінуючі начала: природні задатки до використання найпростіших форм поведінки просоціального типу та соціалізуючі впливи дорослих. Інструментальна допомоги $\epsilon$ найлегшою формою просоціальних виявів для дітей раннього віку. Ї̈ розвиток відбувається у взаємозв'язку із змінами у когнітивній сфері та структурах самоусвідомлення. Поява допомагаючи дій сприяє розвитку співробітництва, альтруїзму, засвоєння норм. Питання розвитку допомоги у період дошкільного дитинства проаналізовано у роботах Андрєєва, 2008; Наy, 2009; Rapp, 2017. Так, Андреєва виокремлює три рівні готовності дітей дошкільного віку до взаємодопомоги: прагматичний, формально-рольовий та дієвий. Зміни, що відбуваються у просоціальній активності цього типу у період молодшого шкільного віку описані у дослідженнях Павелківа, 2004; Gini, 2007. Встановлено, що протягом періоду відбувається урізноманітнення просоціальних дій сприяння. Система соціальних орієнтацій доповнюється механізмом переваг щодо членів своєї групи, врахування презентаційних аспектів ситуації. Діти набувають здатність помічати необхідність допомоги без наявності звертання за нею.

Інформацію про розгортання допомоги як просоціальної стратегії у підлітковий i юнацький період представлено у роботах Булах, 2016; Кухтової, 2011; Наконечної, 2012; Eisenberg, 2002. В цілому, працюючи над змістовим контентом просоціальної проблематики необхідно забезпечити для студентів усвідомлення основних змін, що відбуваються у допомагаючій поведінці особистості впродовж онтогенезу: підвищення рівня добровільності і усвідомленості дій, перехід від епізодичних видів допомоги до систематичних форм сприяння, підвищення коректності підтримки партнера, зростання частоти сприяння, розширення форм і стратегій допомоги іншим та ін.

Основну увагу при плануванні програми просоціальної освіти у курсі вікової психології необхідно зосередити на виокремленні і описі основних етапів становлення особистісного утворення «просоціальність», механізмах його функціонування. Як зазначається у нашому дослідженні, у розвитку просоціальності можна виокремити шість якісно своєрідних етапів іiї становлення : етап елементарної просоціальності, етап соціальнонормативної просоціальності, етап нормативно-диспозиційної просоціальності, етап позиційної просоціальності, етап особистісно-досягнутої просоціальності, і нарешті 
інтегративного утворення просоціальності. Кожний із цих етапів розгортається у межах певного вікового періоду чи певної вікової епохи (як це наприклад спостерігається на другому етапі становлення особистісного конструкту, становлення якого відбувається протягом двох вікових періодів : дошкільного та молодшого шкільного віку).

Вікова генеза просоціальності значною мірою пов'язана із рівнем сформованості психологічних механізмів, що забезпечують для особистості здатність виокремлювати ситуації із просоціальним контекстом та приймати відповідні рішення. До найпростіших механізмів елементарної просоціальності належать первинні механізми соціальної перцепції, вроджені емпатійні установки, та здатність дітей раннього віку до наслідування. У період дошкільного та молодшого шкільного віку система просоціальних механізмів доповнюються здатністю дітей до інтеріоризації, появи механізмів рефлексії, ідентифікації та емоційного перемикання. 3 переходом до підліткового віку просоціальний розвиток пов'язаний із функціонуванням моральної рефлексії, емпатії, інтеріоризації та ідентифікації. 3 переходом до юнацького періоду просоціальні самовияви реалізуються на основі механізмів цілепокладання, емпатії та моральної рефлексії. 3 переходом до дорослого віку центральну позицію у системі психологічних механізмів особистісних самовиявів займає механізм смислоутворення. Як засвідчили результати дослідження смислотворення у поєднанні із механізмом ретроспекції забезпечує людині творчу, духовну просоціальну самореалізацію на основі використання про соціального досвіду та усталених патернів гуманістичної поведінки (Корчакова, 2018, с.18).

Висвітлення процесу вікового генезу просоціальності у курсі вікової психології повинно передбачати аналіз змін у структурі особистісного феномену та його змістовому наповненні. Якщо на початкових етапах розвитку особистісної якості іiі поведінкові вияві спиралися лише на емоційні та когнітивні структури, то з переходом до епохи дошкільного та молодшого шкільного віку у свідомості дитини викристалізовується мотиваційна складова: спочатку мотиваційно-нормативного, потім мотиваційно-ціннісного i нарешті мотиваційно-смислового та мотиваційно-інтегративного рівня, що поєднуються із розвитком когнітивно-рефлексивних здатностей особистості. Про цілісний конструкт просоціальності як особистісної якості доречно говорити із підліткового періоду, коли домінуючу функцію у структурі феномену

Важливими аспектами розкриття генези просоціальності у процесі викладання курсу вікової психології є виокремлення питань ії рівневих характеристик. На основі емпіричних даних можна говорити про чотири рівні сформованості і функціонування особистісної якості: імпульсивно-ситуативний рівень, рівні інертної та зрілої просоціальності і її найвища рівнева ступінь - альтруїзму. Варто зазначити, що при висвітленні інформації щодо рівневих характеристик сформованості просоціальності особистості особливу увагу доречно зосереджувати на усвідомленні студентами різниці у соціальній та психологічній сутності двох найвищих рівнів сформованості гуманістично зорієнтованої якості. Зріла просоціальність та альтруїзм різняться двома параметрами: рівнем соціальної значущості вчинку та його роллю у становленні особистості. Згідно соціальної цінності вчинку вище визнання отримують альтруїстичні самовияви особистості, у той час як дії на основі зрілої просоціальності є більш значущими для ії самосприйняття і особистісного розвитку. Саме за умов зрілих просоціальних самовиявів поведінка суб'єкта просоціального сприяння стимулюється отриманням психологічних вигод: соціальним визнанням, відчуттям власної цінності, самоповагою, що у подальшому підкріплюють просоціальний Я-образ.

Отже, просоціальна проблематика повинна доповнити змістовий контент дисциплін психологічного циклу, що викладаються у вищій школі при підготовці майбутніх вчителів і психологів. У курсах соціальної і вікової психології студенти повинні отримати знання за результатами сучасних досліджень щодо природи, сутності і вікової генези унікального різновиду соціальної поведінки людини - іiї дій на благо Іншого. 


\section{СПИСОК ПОСИЛАНЬ}

Андреев, П. В. (2008) Психолого-педагогические условия развития психологической готовности дошкольников к взаимопомоши (Автореф. дис. канд. психол. наук.). Самарский государственный педагогический университет.Самара.

Багмет, I. М.(2001) Вікові прояви альтруїзму-егоїзму та їх диференціація. Вісник Одеського наи. ун-ту. Серія: Психологія. 6, 2,16-20.

Булах, І. С.(2016) Психологія особистісного зростання підлітків: реалї̈ та перспективи . Вінниця.

Игнацкая, О. Е.(2012) Развитие просоциальной направленности личности в онтогенезе // 36. навук. праи Акадэміі паслядыпл адукащылі, 10, 197 - 211.

Корчакова, Н. В. (2017) Просоціальність особистості : становлення та розвиток. Рівне: Волинські обереги.

Корчакова, Н. В.(2018) Вікова генеза просоиіальності особистості (Автореф. дис.... д-ра психол. наук). Національний педагогічний університет ім. М.П.Драгоманова. Київ.

Кириченко, В. І.(2014) Сучасні підходи до формування просоціальної поведінки учнів. // Сучасний виховний процес: сутність та інноваційний потенціал, 84-86.

Кухтова, Н. В., Домарацкая, Н.В. (2011) Просоциальное поведение специалистов, ориентированных на оказание помощи: теоретические основы и методики. Витебск : Изд-во УО «ВГУ им. П. М. Машерова».

Наконечна, М. М.(2012) Допомога іншому: психологічний аспект.Київ : Вид. Дім «Слово».

Павелків Р. В., Корчакова, Н. В.(2013) Просоиіальний розвиток особистості : монографія .Рівне : Вид. О. Зень.

Павелків, Р. В.(2004) Розвиток моральної свідомості та самосвідомості у дитячому віці: монографія .Рівне: Волинські обереги.

Bischof-Köhler, D.(2011) Soziale Entwicklung in Kindheit und Jugend. Bindung, Empathie, Theory of Mind. - Stuttgart: Kohlhammer, 484 S., URL: http://www.ciando.com/ebook/bid990263

Bierhoff, H.-W. and Rohmann, E. (2004), Altruistic personality in the context of the empathyaltruism hypothesis. Eur. J. Pers., 18: 351-365. https://doi.org/10.1002/per.523

Brownell, C. A., Ramani, G. B., \& Zerwas, S. (2006). Becoming a social partner with peers: cooperation and social understanding in one- and two-year-olds. Child development, 77(4), 803-821. https://doi.org/10.1111/j.1467-8624.2006.00904.x

Carlo, G., Randall, B.A. The Development of a Measure of Prosocial Behaviors for Late Adolescents. Journal of Youth and Adolescence 31,31-44 (2002). https://doi.org/10.1023/A:1014033032440

Dunfield K. A. (2014). A construct divided: prosocial behavior as helping, sharing, and comforting subtypes. Frontiers in psychology, 5, 958. https://doi.org/10.3389/fpsyg.2014.00958.

Eisenberg, N. (2015). Prosocial Development. In N. Eisenberg, W. Damon, \& R. M. Lerner (Eds.), Handbook of child psychology: Social, emotional, and personality development (p. 610-656).

Gini, G., Albiero, P., Benelli, B., \& Altoè, G. (2007). Does empathy predict adolescents' bullying and defending behavior?. Aggressive behavior, 33(5), 467-476. https://doi.org/10.1002/ab.20204

Hay, D. F. (2009). The roots and branches of human altruism. British Journal of Psychology, 100(3), 473-479. https://doi.org/10.1348/000712609X442096

Hepach, R. (2016). Prosocial Arousal in Children. Child Development Perspectives. 10.1111/cdep. 12209.

Hepach, R., Vaish, A., \& Tomasello, M. (2013). A new look at children's prosocial motivation. Infancy, 18(1), 67-90. https://doi.org/10.1111/j.1532-7078.2012.00130.x.

House, B. R., Henrich, J., Brosnan, S. F., \& Silk, J. B. (2012). The ontogeny of human prosociality: Behavioral experiments with children aged 3 to 8. Evolution and Human Behavior, 33(4), 291-308. https://doi.org/10.1016/j.evolhumbehav.2011.10.007 
Nantel-Vivier, A., Kokko, K., Caprara, G. V., Pastorelli, C., Gerbino, M. G., Paciello, M., Côté, S., Pihl, R. O., Vitaro, F., \& Tremblay, R. E. (2009). Prosocial development from childhood to adolescence: a multi-informant perspective with Canadian and Italian longitudinal studies. Journal of child psychology and psychiatry, and allied disciplines, 50(5), 590-598. https://doi.org/10.1111/j.1469-7610.2008.02039.x

Paulus, M. (2015). Children's inequity aversion depends on culture: A cross-cultural comparison. Journal of Experimental Child Psychology, 132, 240246. https://doi.org/10.1016/j.jecp.2014.12.007

Paulus, M. (2014), The Emergence of Prosocial Behavior: Why Do Infants and Toddlers Help, Comfort, and Share?. Child Dev Perspect, 8: 77-81. https://doi.org/10.1111/cdep.12066

Penner, L. A. (2002). Dispositional and organizational influences on sustained volunteerism: An interactionist perspective. Journal of Social Issues, $58(3), \quad 447-$ 467. https://doi.org/10.1111/1540-4560.00270

Rapp, D. J., Engelmann, J. M., Herrmann, E., \& Tomasello, M. (2017). The impact of choice on young children's prosocial motivation. Journal of Experimental Child Psychology, 158, 112-121. https://doi.org/10.1016/j.jecp.2017.01.004

Rushton, P., \& Irwing, P. (2011). The general factor of personality: Normal and abnormal. In T. Chamorro-Premuzic, S. von Stumm, \& A. Furnham (Eds.), The Wiley-Blackwell handbooks of personality and individual differences. The Wiley-Blackwell handbook of individual differences , 132-161.

Svetlova, M., Nichols, S. R., \& Brownell, C. A. (2010). Toddlers' prosocial behavior: from instrumental to empathic to altruistic helping. Child development, 81(6), 1814-1827. https://doi.org/10.1111/j.1467-8624.2010.01512.x

Tomasello, M., \& Vaish, A. (2013). Origins of human cooperation and morality. Annual review of psychology, 64, 231-255. https://doi.org/10.1146/annurev-psych-113011-143812

Warneken, F., \& Tomasello, M. (2013). Parental presence and encouragement do not influence helping in young children. Infancy, 18(3), 345-368. https://doi.org/10.1111/j.15327078.2012.00120.x

\section{REFERENCES}

Andreev, P. V.(2008) Psykholoho-pedahohycheskye uslovyia razvytyia psykholohycheskoi hotovnosty doshkolnykov k vzaymopomoshchy [psychological and pedagogical condition of development of] (Avtoref. dyc. kand. psykhol. nauk.). Samarskyi hosudarstvennui pedahohycheskyi unyversytet.Samara.

Bahmet, I. M.(2001) Vikovi proiavy altruizmu-ehoizmu ta yikh dyferentsiatsiia. Visnyk Odeskoho nats. un-tu. Seriia: Psykholohiia. 6, 2,16-20.

Bulakh, I. S.(2016) Psykholohiia osobystisnoho zrostannia pidlitkiv: realii ta perspektyvy . Vinnytsia.

Yhnatskaia, O. E.(2012) Razvytye prosotsyalnoi napravlennosty lychnosty v ontoheneze // Zb. navuk. prats Akadэmii pasliadыpl adukatsыi,10, $197-211$.

Korchakova, N. V. (2017) Prosotsialnist osobystosti : stanovlennia ta rozvytok. Rivne: Volynski oberehy.

Korchakova, N. V.(2018) Vikova geneza prosotsialnosti osobystosti (Avtoref. dys.... d-ra psykhol. nauk). Natsionalnyi pedahohichnyi universytet im. M.P.Drahomanova. Kyiv.

Kyrychenko, V. I.(2014) Suchasni pidkhody do formuvannia prosotsialnoi povedinky uchniv. // Suchasnyi vykhovnyi protses: sutnist ta innovatsiinyi potentsial, 84-86.

Kukhtova, N. V., Domaratskaia, N. V. (2011) Prosotsyalnoe povedenye spetsyalystov, oryentyrovannыkh na okazanye pomoshchy: teoretycheskye osnovы y metodyky. Vytebsk Vzd-vo UO «VHU ym. P. M. Masherova».

Nakonechna, M. M.(2012) Dopomoha inshomu: psykholohichnyi aspekt.Kyiv : Vyd. Dim «Slovo».

Pavelkiv R. V., Korchakova, N. V.(2013) Prosotsialnyi rozvytok osobystosti : monohrafiia .Rivne : Vyd. O. Zen. 
Pavelkiv, R. V.(2004) Rozvytok moralnoi svidomosti ta samosvidomosti u dytiachomu vitsi: monohrafiia .Rivne: Volynski oberehy

Bischof-Köhler, D.(2011) Soziale Entwicklung in Kindheit und Jugend. Bindung, Empathie, Theory of Mind. - Stuttgart: Kohlhammer, 484 S., URL: http://www.ciando.com/ebook/bid990263

Bierhoff, H.-W. and Rohmann, E. (2004), Altruistic personality in the context of the empathyaltruism hypothesis. Eur. J. Pers., 18: 351-365. https://doi.org/10.1002/per.523

Brownell, C. A., Ramani, G. B., \& Zerwas, S. (2006). Becoming a social partner with peers: cooperation and social understanding in one- and two-year-olds. Child development, 77(4), 803-821. https://doi.org/10.1111/j.1467-8624.2006.00904.x

Carlo, G., Randall, B.A. The Development of a Measure of Prosocial Behaviors for Late Adolescents. Journal of Youth and Adolescence 31, 31-44 (2002). https://doi.org/10.1023/A:1014033032440

Dunfield K. A. (2014). A construct divided: prosocial behavior as helping, sharing, and comforting subtypes. Frontiers in psychology, 5, 958. https://doi.org/10.3389/fpsyg.2014.00958.

Eisenberg, N. (2015). Prosocial Development. In N. Eisenberg, W. Damon, \& R. M. Lerner (Eds.), Handbook of child psychology: Social, emotional, and personality development ( $\mathrm{p}$. 610-656).

Gini, G., Albiero, P., Benelli, B., \& Altoè, G. (2007). Does empathy predict adolescents' bullying and defending behavior?.Aggressive behavior, 33(5), 467-476. https://doi.org/10.1002/ab.20204

Hay, D. F. (2009). The roots and branches of human altruism. British Journal of Psychology, 100(3), 473-479. https://doi.org/10.1348/000712609X442096

Hepach, R. (2016). Prosocial Arousal in Children. Child Development Perspectives. 10.1111/cdep.12209.

Hepach, R., Vaish, A., \& Tomasello, M. (2013). A new look at children's prosocial motivation. Infancy, 18(1), 67-90. https://doi.org/10.1111/j.1532-7078.2012.00130.x.

House, B. R., Henrich, J., Brosnan, S. F., \& Silk, J. B. (2012). The ontogeny of human prosociality: Behavioral experiments with children aged 3 to 8. Evolution and Human Behavior, 33(4), 291-308. https://doi.org/10.1016/j.evolhumbehav.2011.10.007

Nantel-Vivier, A., Kokko, K., Caprara, G. V., Pastorelli, C., Gerbino, M. G., Paciello, M., Côté, S., Pihl, R. O., Vitaro, F., \& Tremblay, R. E. (2009). Prosocial development from childhood to adolescence: a multi-informant perspective with Canadian and Italian longitudinal studies. Journal of child psychology and psychiatry, and allied disciplines, 50(5), 590-598. https://doi.org/10.1111/j.1469-7610.2008.02039.x

Paulus, M. (2015). Children's inequity aversion depends on culture: A cross-cultural comparison. Journal of Experimental Child Psychology, 132, 240246. https://doi.org/10.1016/j.jecp.2014.12.007

Paulus, M. (2014), The Emergence of Prosocial Behavior: Why Do Infants and Toddlers Help, Comfort, and Share?. Child Dev Perspect, 8: 77-81. https://doi.org/10.1111/cdep.12066

Penner, L. A. (2002). Dispositional and organizational influences on sustained volunteerism: An interactionist perspective. Journal of Social Issues, 58(3), 447467. https://doi.org/10.1111/1540-4560.00270

Rapp, D. J., Engelmann, J. M., Herrmann, E., \& Tomasello, M. (2017). The impact of choice on young children's prosocial motivation. Journal of Experimental Child Psychology, 158, 112-121. https://doi.org/10.1016/j.jecp.2017.01.004

Rushton, P., \& Irwing, P. (2011). The general factor of personality: Normal and abnormal. In T. Chamorro-Premuzic, S. von Stumm, \& A. Furnham (Eds.), The Wiley-Blackwell handbooks of personality and individual differences. The Wiley-Blackwell handbook of individual differences , 132-161.

Svetlova, M., Nichols, S. R., \& Brownell, C. A. (2010). Toddlers' prosocial behavior: from instrumental to empathic to altruistic helping. Child development, 81(6), 1814-1827. https://doi.org/10.1111/j.1467-8624.2010.01512.x 
Tomasello, M., \& Vaish, A. (2013). Origins of human cooperation and morality. Annual review of psychology, 64, 231-255. https://doi.org/10.1146/annurev-psych-113011-143812

Warneken, F., \& Tomasello, M. (2013). Parental presence and encouragement do not influence helping in young children. Infancy, 18(3), 345-368. https://doi.org/10.1111/j.15327078.2012.00120.x

\title{
PROBLEM OF HUMAN PROSOCIAL DEVELOPMENT IN A STRUCTURE OF EDUCATIONAL CONTENT
}

Roman Pavelkiv

Doctor of psychological sciences, professor, Head of the Department of Lifespan \& Pedagogical Psychology http://orcid.org/0000-0002-6564-4507

Natalia Korchakova

Doctor of psychological sciences, professor, Department of Life-span and Pedagogical Psychology

Rivne State University of the Humanities http://orcid.org/0000-0003-1164-3370

Valentyna Bezliudna

Candidate of pedagogical sciences, professor, Department of Lifespan \& Pedagogical Psychology http://orcid.org/0000-0003-3276-3427 DOI https://doi.org/10.35619/praprv.v1i15.194

\begin{abstract}
Necessity of modernization and development of academic educational programs is discussed in the presented article. It is noted that transformation of university education in Ukraine requires the updating of informational content offered to the future professionals. Selection of the newest ideas and inclusion them into the structure of academic courses are the important tasks of modern education. Prosocial development, as a new area of psychological research, should take its rightful place within the educational programs for human-oriented specialists. Prosocial behavior is considered a special type of person's social activity focused on supporting the Others, providing them with assistance and helping them in realization of their intentions. The authors emphasize that the dispositional basis, underling that type of behavior, is prosociality -a personal trait that has a complex structure and a long path of ontogenetic formation.

On the authors opinion the issue of human prosociality should be included in the curriculum of such disciplines as developmental and social psychology. However, the presentation of certain issues of the problem should be consistent with the main objectives of the courses. Within the course of social psychology, it is worth to familiarize the future psychologists and teachers with the essence of the concepts of "prosocial behavior" and "prosociality", their dispositional and situational determination, the main types of short-term and long-term forms of social behavior. The program of developmental psychology should be supplemented with materials of age-related genesis of prosociality and prosocial behavior from the emergence of elementary forms of assistance in early childhood to mature forms of individual's behavior in adulthood.
\end{abstract}

Key words: educational content, university courses, prosocial behavior, human prosociality, genesis, students. 